\title{
DEVELOPING COOPERATIVE LEARNING BASED MODULE FOR TEACHING READING TO THE SECOND SEMESTER STUDENTS AT ENGLISH DEPARTMENT OF FKIP - UIR
}

\author{
Safriyani Novitri \\ Islamic University of Riau \\ email: safriyaniazzahra@ymail.com
}

\begin{abstract}
This research is designed to develop the students' reading comprehension of narrative, descriptive and hortatory exposition texts by using cooperative learning based-module. It aims to explain the current needs, to design and to examine the validity and practicality of cooperative learning based-module in developing reading comprehension at the second-semester Students in English Department of FKIP - UIR. The design of this research is R \& D approach by using ADDIE model. The sample was selected from second semester students at English Department of FKIP UIR. Five validators involved in evaluating the product to evaluate its the validity, and the practicality. The quantitative data were collected through a questionnaire and test and qualitative data were collected through an interview. To develop the learning material to be given to students, the researcher tried to find out the need analysis, the validity, and the practicality of her product in designing and implementing reading in cooperative learning basedmodule. Based on the research finding of this research was considered valid and practice and it can be used to develop the quality of students in reading comprehension.
\end{abstract}

Keywords: Cooperative Learning Based-Module, Teaching, Reading.

\section{PENGEMBANGAN MODULE PEMBELAJARAN MEMBACA BERBASIS PEMBELAJARAN KOOPERATIF}

\begin{abstract}
Abstrak
Penelitian ini dirancang untuk mengembangkan modul pembelajaran membaca mahasiswa berbasis pembelajaran kooperatif. Tujuan penelitian adalah untuk menjelaskan kebutuhan mahasiswa saat ini, merancang modul pembelajaran dan menguji validitas, dan kepraktisan membaca berbasis pembelajaran kooperatif pada Mahasiswa Semester dua di Jurusan Bahasa Inggris FKIP - UIR. Desain
\end{abstract}


penelitian ini adalah R \& D dengan menggunakan model ADDIE. Sampel dalam penelitian ini diambil dari mahasiswa semester II. Lima validator terlibat dalam mengevaluasi produk berkenaan dengan validitas, dan kepraktisan. Data kuantitatif dikumpulkan melalui kuesioner dan tes, data kualitatif dikumpulkan melalui wawancara. Peneliti memulai dari analisis kebutuhan, validitas, dan kepraktisan produk dalam merancang dan mengimplementasikan modul pembelajaran berbasis pembelajaran kooperatif untuk pengajaran membaca. Berdasarkan hasil penelitian, produk dinyatakan valid dan praktis. Produk mudah digunakan dan dapat meningkatkan kualitas pemahaman membaca mahasiswa. Kesimpulan, pengembangan modul pembelajaran berbasis pembelajaran kooperatif untuk pengajaran membaca memberikan kontribusi yang sangat besar khususnya pada pemahaman membaca mahasiswa. Kontribusi ini akan mengarahkan peneliti selanjutnya untuk mengembangkan dan mengadopsi modul membaca untuk pengayaan pada model pembelajaran.

\section{Keywords : Pengembangan Module pembelajaran membaca, berbasis kooperatif}

\section{INTRODUCTION}

A module is one kind of teaching materials prepared by the lecturer and given to the students to support teaching and learning process. Gibbs (1995: 30) defines a module as a paper-based resource used to support teaching and learning which can release students from excessive note taking or supplement information which is not easily available elsewhere. Ideally, a module should aid learning, increase attention and motivation and help students follow the development of an idea or argument.

Based on the researcher's experience and some information got from other lecturers that have taught reading at second semester of English Department of FKIP-UIR, the researcher found some problems faced by students in learning to read

J-SHMIC, Vol 4, No 1, February 2017 comprehensively. Some of the students' problems in reading are the texts used by the lecturer. The materials are so difficult that students do not know how to work collaboratively.

As the lecturer observed during teaching and learning process in her reading class, the lecturer found that the students had problems in reading comprehension. Even though she had made some efforts to develop her students' reading comprehension, her students still had difficulties to comprehend the text precisely. The researcher observed 38 students at semester II/F of English Department of FKIP-UIR Pekanbaru, and found that the reading comprehension was still low. There were only 11 students who were able to answer the questions of the text correctly in the

Developing Cooperative Learning Based Module for Teaching Reading to the Second Semester Students at English Department of FKIP-UIR 
midterm. There were 15 students, who were able to give responses to the lecturer's questions, but they only copied the sentences of the text directly; they did not make any inferences on their answers. Sometimes, they put all texts in answering the questions. The average score of students' reading comprehension in midterm was as follows; the students' scores the main idea were 62.42. They got 53.62 for details. They got 55 for vocabulary. They got 65.50 for reference, and they got 53.47 for inference. Therefore, the total of the average score was 58.89. These scores indicated that students' ability in each aspect of reading comprehension was unsatisfying.

Furthermore, the lecturer investigated the cause of the students' problem in reading comprehension. The lecturer found there were some factors that impacted the students' ability in comprehending the text. First, most of the students had difficulty to take the information of the text. When the students read a reading text, they remembered the text for the second time; then, they forgot what the text was. It could be seen when the lecturer asked them to express the information of the text that they have already read. They were not able to do it because they only read the text without jotting down any information from the text, and they did not attempt to discuss the text in the pair. It happened because many students tended to read the text by looking up the meaning of the word by word without connecting one idea to another in the text. It made them fail to answer the questions when they were given a task or test by the lecturer.

Second, the students were confused and not confident with the information that they got from the text. As a result, they were not able to understand the meaning of the text precisely. It could be seen from their answer sheet. They answered the questions by copying all sentences from the text. They did not infer from the text that they read to get the meaning of the text because they were afraid of making mistakes. They only copied the sentences in the text into their answer sheet since they doubted with their understanding of the text; thus, they think that copying all sentences to the answer sheet would prevent them to make mistakes. It indicated that the students need to reinforce their confidence in inferring the issues they took from the text.

Currently, the lecturer uses the conventional strategy in teaching reading at semester II/F of the English Department of FKIP-UIR. She gives a text to the students, asks them to identify the main idea and detail and asks them to answer the questions directly. This strategy is still not effective and appropriate. As the result, the students are rather unmotivated to comprehend the reading texts. The materials that are available in the textbooks are not used optimally to develop students creativity in reading classes. The content of the instructional material is not suitable for the students so that they find great difficulties in studying 
reading. Furthermore, exercises which are included in the text do not support students creativity; the potential materials do not give the opportunity to develop students necessary skills. It means that materials do not provide opportunities for students to response well about the material given to them. In addition, the second-semester students in the English Department of the Islamic University of Riau have low motivation and ability in reading because the lecturer has not designed an interesting and creative English instructional package.

Based on these problems, the researcher intends to develop a module of reading comprehension with cooperative learning basedmodule to solve these problems. By using the module, the students have opportunities to learn by themselves. The researcher assumes that the solution to the students' problems in reading comprehension is by using modules because this instructional package is not only expected to become a learning source for English instruction but also hoped to build high motivation and creativity of the students and develop the quality of their studying.

A module is a set of instructional materials presented systematically so that the students can learn with or without a lecturer. Thus, a module should be used as material to substitute lecturer's presence. If the lecturer has to explain something, then the module must be able to explain what the lecturer does. It is expected that language learners can accept it in accordance with the level of knowledge and age.

The instructional model used in reading is cooperative learning based-module. This module can be said similar to constructivist instructional design which gives many opportunities for students to construct their reading ability to become more innovative and creative. In this module, the researcher attempts to combine the principles of cooperative learning with experiences in using some cooperative learning techniques. It means that, instead of exploring the different attributes of cooperative learning as a concept by sticking to content about cooperative learning, most of the sessions focus on illustrating the components of cooperative learning that are used as classroom content for the secondsemester students of the English Department of the Islamic University of Riau.

The activities in the module are designed to enable the students to reflect on what happened in the actual reading lessons and identify the attributes of the cooperative learning technique used. It implies that reflecting on the concepts of the cooperative learning get discussed together in their classroom. Thus, by using cooperative learning, the students become more active and are able to share their ideas with their friends.

Many of the activities, discussions and laboratory activities involve pedagogical approaches by 
means of the base of cooperative learning. Cooperative learning is based on the belief that learning is an active and constructive process, and the students are organizing their ideas and giving explanations, as well as reading to alternate or conflicting ideas. Cooperative learning incorporates respect for students of all backgrounds, and it stresses that all students can be successful academically. A research shows that students take benefit from cooperative learning in three major areas. These areas are academic achievement, positive relationships between students, and psychological health including self-esteem (Johnson, 1994).

Cooperative learning which is an internationally recognized pedagogical approach to increase student's participation and interaction in teaching and learning focus on building competencies in academic, social, and life skills of learners, as well as developing classroom practices of lecturers. Cooperative learning is a well-designed teaching in which teachers need to be well trained and need regular mentoring and support.

\section{Continuous professional} development of lecturers which is fundamental in building source in education has been given most prominence in the module through professional mentoring, support supervision by lecturers and peers. This is intended to go a long way in supporting reading, lecturers to develop students skills, knowledge and attitudes as pedagogical professionals. Modules also provide pictures for every material in order to make it more interesting for students. The picture is designed to develop students' reading activity and exchange their ideas in order to share in their group.

Based on the explanation above, it is assumed that cooperative learning provides interesting activities for students to learn reading. As a result, it is beneficial to develop cooperative learning based-module to teaching reading of the second semester of English Department students at FKIP - UIR.

The module is defined as a set of teaching materials are presented in a systematic way so that users can learn with or without a facilitator or teacher. The systematic intention is by module, learners can measure their own level of mastery of the material covered in each unit module, so if it has been mastered then they can continue to the next level module unit. Otherwise, if the students have not been able to master, then they can repeat and relearn (Depdiknas, 2004).

Based on the characteristic of module by Prastowo (2011) in teaching and learning process include: First, self-instruction that means training or participants are able to teach themselves, not depend on others. Second, self-contained that means all learning materials from one unit of competency or subcompetency learned available in one single module intact. Third, 
depandable is module manual/multimedia developed that is not dependent on other media or should not be used together with other media. Fourth, adaptive module, for additional insight module that means module should have a high power to the development of science and technology. Fifth, systematic that means the module is interpreted as a set of teaching materials presented systematically so that users can learn with or without a facilitator or teacher.

Preparing the modules and the forms of the module, the researcher used cooperative learning based. Cooperative learning is group learning activity organized so that learning is dependent on the socially structured exchange of information between learners in groups and in which each learner is held accountable for his or her own learning and is motivated to increase the learning of others (Olsen and Kagan 1992).

In another word, cooperative learning is a systematic pedagogical strategy that encourages small groups of students to work together for the achievement of a common goal. The term collaborative learning is often used as a synonym for cooperative learning, when in fact, it is a separate strategy that encompasses broader range interactions such as developing learning communities, stimulating students/faculty discussions, and encouraging electronic exchanges (Bruffee, 1993). Both approaches stress the importance of faculty and student involvement in the learning process. When integrating cooperative or collaborative learning strategies into a course, careful planning and preparation are essential.

Based on the explanation above the object of learning modules is to provide the students with necessary information and skills and awareness so that the students can collaborate in the development of their knowledge. The outcomes are the interpersonal communication skills, with cooperative learning used to describe a deliberate use of cooperative learning in the learning environment. Collaborative technologies allow production of shared knowledge and new community practices.

Kasler (1992) defines
cooperative learning as group
learning through exchange of
information among the learners in a
group in order to motivate them to
learn through social interaction within
the group. Slavin (1995) defines
cooperative learning as an
instructional model where students
work together on all levels of
performance toward a group goal. It
involves all the levels of
comprehension of the students,
whether they are in a low or high
level of comprehension. All the levels
of comprehension of the students are
put together in order to achieve the
goal a group and to comprehend what
they are reading.

Developing Cooperative Learning Based Module for Teaching Reading to the Second Semester Students at English Department of FKIP-UIR 
Farnish (1995) describes cooperative learning and reading materials as a comprehensive program for teaching reading and writing /language arts. It has three basic elements: first is text-related activities, direct instruction in reading comprehension, and integrated language arts/writing. Second is the students are assigned to work in reading groups. They are engaged in activities related to the reading text. The third is reading to each other, predicting the meaning of the text in general, summarizing the text, writing the responses, practicing spelling, decoding, and vocabulary. In most cooperative learning activities, students follow a sequence of teacher instructions, team practice, peer preassessments, assessment, and team recognition.

Cooperative learning and reading materials tend the approach in both group and individual. Cooperative learning in reading is developed to integrate the writing and reading lessons. The main activities in cooperative learning in reading materials are: Firstly, reading to each other, secondly, predicting the meaning of the text, thirdly, last summarizing text to each other, fourth, writing responses to text and fifth, practicing, spelling, decoding, and vocabulary.

\section{METHOD}

This research used the procedural model of development implemented to develop cooperative learning based-module. It means this research was conducted based on the stages to be followed to produce a valid reading module.

Therefore, the instructional model used to develop cooperative learning based-module in teaching reading in this research follows the ADDIE model as proposed by Gustafson \& Branch (2002). The researcher chooses ADDIE model because of Analyze, Design, Develop, Implement, and Evaluate (ADDIE) describes a process applied to instructional design in order to generate episodes of intentional learning. This section presents an overview of the purpose, procedures, and deliverable commonly associated with each of the five ADDIE phases. The purpose of the Analyze phase is to identify the probable causes for a performance gap. In this case, the researcher found the gap between the present condition of Second Semester Students in English Department of FKIP - UIR and the expected result of reading comprehension.

The participants of this research were the English students at the second semester of the English Department of FKIP-UIR class F in academic year 2013. The data in the research were gathered from: (1) Questionnaire, (2) Validation sheet, (3) interview, (4) Evaluation sheet.

\section{FINDINGS AND DISCUSSION}

\section{a.The current needs of Second Semester Students in English Department of FKIP - UIR}

Researcher have carried out the questionnaire for the students, it 
turned out that they have different characteristics, in terms of ability, learning motivation, learning, and activeness. Based on the analysis of student learning outcomes, the researcher obtained the information that the ability of the students can be categorized into three categories: high, medium and low and each student has different learning speeds. In classical learning systems such as; read the text then identified the main idea and detail, and then answered the questions directly, need to develop an optimal capability because students who learn quickly have to wait for students who learn slowly.

\section{b. The Design of Cooperative Learning Based}

Figure 1. The Design of Research Product

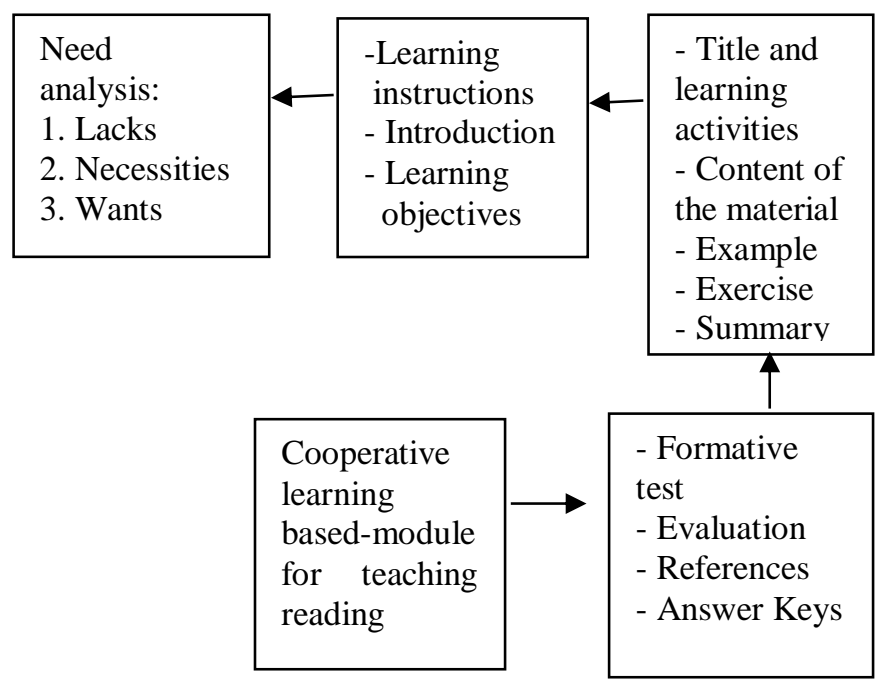

J-SHMIC, Vol 4, No 1, February 2017

\section{c. The Developing of Cooperative Learning Based-Module}

Figure 2. Steps in Developing Cooperative Learning Based-Module

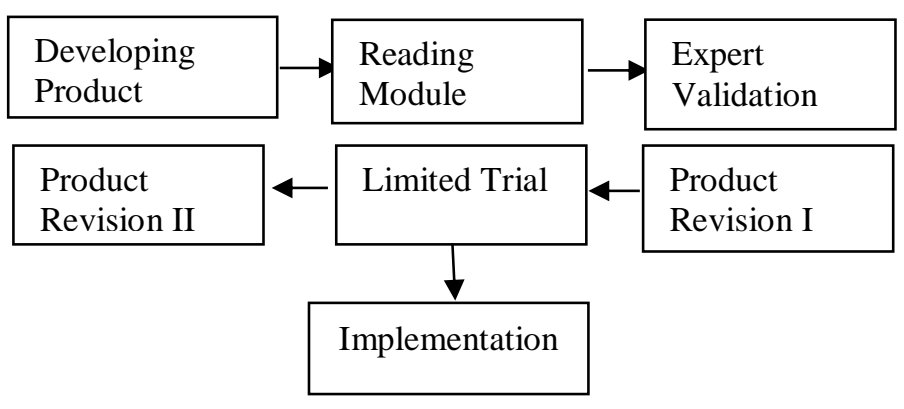

d. Implementation of Product

The product was used in second semester of the English Department of FKIP-UIR in academic year 2013. The researcher implemented cooperative learning based-module in teaching reading, the activities of implementing was done once a week for seven meeting or for a half semester. The reseacher gave pre-test before implementing the product. The purpose was to find out the students' level of reading comprehension. In the last activity, the researcher did evaluation activity for formative test and post-test.

\section{e. Evaluation of Product}

The research product of this research was cooperative learning based-module, this product has been tried out and implemented and the result of implementataion of this cooperative learning based-module after evaluation, there was still needed to be revised in words spelling, the arrangement of fonts, 
and pictures. There were some revisions also in the title and page numbers.

Table 3.1 The Result Score of Narrative Reading Module

\begin{tabular}{|c|c|c|c|}
\hline \multirow{2}{*}{ No } & \multirow{2}{*}{$\begin{array}{l}\text { Name of } \\
\text { Students }\end{array}$} & \multicolumn{2}{|c|}{ Score } \\
\hline & & $\begin{array}{l}\text { Pre- } \\
\text { Test }\end{array}$ & $\begin{array}{c}\text { Post- } \\
\text { Test }\end{array}$ \\
\hline 1 & RAY & 60 & 85 \\
\hline 2 & FR & 60 & 90 \\
\hline 3 & WR & 45 & 75 \\
\hline 4 & RD & 50 & 85 \\
\hline 5 & NW & 45 & 75 \\
\hline 6 & SP & 65 & 85 \\
\hline 7 & RSA & 50 & 80 \\
\hline 8 & $\mathrm{ZM}$ & 50 & 80 \\
\hline 9 & IPP & 60 & 80 \\
\hline 10 & MS & 60 & 85 \\
\hline 11 & NL & 45 & 75 \\
\hline 12 & ATK & 45 & 75 \\
\hline 13 & $\mathrm{AR}$ & 50 & 70 \\
\hline 14 & DSS & 60 & 80 \\
\hline 15 & NR & 70 & 85 \\
\hline 16 & MF & 45 & 75 \\
\hline 17 & $\mathrm{RN}$ & 50 & 80 \\
\hline 18 & SL & 50 & 75 \\
\hline 19 & SN & 60 & 85 \\
\hline 20 & EF & 65 & 80 \\
\hline 21 & SY & 45 & 75 \\
\hline 22 & RK & 50 & 75 \\
\hline 23 & APV & 70 & 80 \\
\hline 24 & LAR & 50 & 75 \\
\hline 25 & $\mathrm{ASH}$ & 45 & 70 \\
\hline 26 & DW & 65 & 80 \\
\hline 27 & $\mathrm{AH}$ & 60 & 75 \\
\hline 28 & $\mathrm{AG}$ & 65 & 75 \\
\hline 29 & DPE & 65 & 80 \\
\hline 30 & $\mathrm{EHH}$ & 65 & 80 \\
\hline 31 & EMS & 65 & 85 \\
\hline 32 & FN & 50 & 75 \\
\hline 33 & FM & 50 & 80 \\
\hline 34 & HD & 65 & 75 \\
\hline 35 & IS & 60 & 75 \\
\hline 36 & NS & 50 & 70 \\
\hline 37 & RM & 55 & 75 \\
\hline 38 & SHA & 65 & 80 \\
\hline \multicolumn{2}{|c|}{ Mean Score } & 62,5 & 82,5 \\
\hline
\end{tabular}

J-SHMIC, Vol 4, No 1, February 2017
Table 3.1 shows the result from score of formative test from the pretest and post-test, there was an improvement result score pre-test mean score was 66,5 and post-test mean score was 82,5 and the improvement score was 16 for a formative test of the reading module with coperative learning. The students in pre-test who got score $<70$ were twenty-nine students, the other nine students got $>70$. After implementing reading module with cooperative learning-based at second semester students of FKIP-UIR, there was a significant effect of improvement score. There were still nineteen students who got score 70 until 75 and there are 29 students got $>80$.

Table 3.2 The Result Score of Descriptive Reading Module

\begin{tabular}{|c|c|c|c|}
\hline \multirow{2}{*}{ No } & \multirow{2}{*}{$\begin{array}{l}\text { Name of } \\
\text { Students }\end{array}$} & \multicolumn{2}{|c|}{ Score } \\
\hline & & $\begin{array}{l}\text { Pre- } \\
\text { Test }\end{array}$ & $\begin{array}{l}\text { Post- } \\
\text { Test }\end{array}$ \\
\hline 1 & RAY & 65 & 80 \\
\hline 2 & FR & 60 & 85 \\
\hline 3 & WR & 55 & 70 \\
\hline 4 & RD & 55 & 80 \\
\hline 5 & NW & 50 & 80 \\
\hline 6 & SP & 65 & 80 \\
\hline 7 & RSA & 65 & 85 \\
\hline 8 & $\overline{Z M}$ & 70 & 85 \\
\hline 9 & IPP & 65 & 80 \\
\hline 10 & MS & 70 & 80 \\
\hline 11 & $\mathrm{NL}$ & 65 & 75 \\
\hline 12 & ATK & 60 & 80 \\
\hline 13 & $\mathrm{AR}$ & 60 & 85 \\
\hline 14 & DSS & 60 & 80 \\
\hline 15 & NR & 70 & 85 \\
\hline 16 & MF & 60 & 85 \\
\hline 17 & $\mathrm{RN}$ & 60 & 80 \\
\hline 18 & SL & 60 & 75 \\
\hline 19 & SN & 65 & 85 \\
\hline 20 & $\mathrm{EF}$ & 70 & 80 \\
\hline
\end{tabular}

Developing Cooperative Learning Based Module for Teaching Reading to the Second Semester Students at English Department of FKIP-UIR 


\begin{tabular}{|c|c|c|c|}
\hline 21 & SY & 65 & 75 \\
\hline 22 & RK & 65 & 75 \\
\hline 23 & APV & 70 & 90 \\
\hline 24 & LAR & 60 & 75 \\
\hline 25 & ASH & 65 & 80 \\
\hline 26 & DW & 65 & 80 \\
\hline 27 & $\mathrm{AH}$ & 65 & 75 \\
\hline 28 & $\mathrm{AG}$ & 65 & 75 \\
\hline 29 & DPE & 65 & 80 \\
\hline 30 & EHH & 65 & 80 \\
\hline 31 & EMS & 65 & 85 \\
\hline 32 & FN & 65 & 75 \\
\hline 33 & FM & 50 & 80 \\
\hline 34 & HD & 65 & 80 \\
\hline 35 & IS & 60 & 85 \\
\hline 36 & NS & 65 & 80 \\
\hline 37 & RM & 65 & 85 \\
\hline 38 & SHA & 65 & 85 \\
\hline & core & 67,5 & 82,5 \\
\hline
\end{tabular}

Table 3.2 shows the result score of a formative test from the pre-test and the post-test, there was an improvement result score pre-test mean score was 67,5 and post-test mean score was 82,5 and the improvement score was 15 for a formative test of reading module with cooperative learning-based. The students in pre-test who got score < 70 were twenty eight students, the other ten students got $>70$. After implementing reading module with cooperative learning-based at second semester students of FKIP-UIR, there was a significant effect of improvement score. There were still 10 students who got score 70 until 75 and there are 28 students got $>80$.

Table 3.3 The Result Score of Hortatory Exposition Reading Module

\begin{tabular}{|l|c|c|c|}
\hline \multirow{2}{*}{ No } & \multirow{2}{*}{$\begin{array}{c}\text { Name of } \\
\text { Students }\end{array}$} & $\begin{array}{c}|c| \\
\text { Pre- } \\
\text { Test }\end{array}$ & $\begin{array}{c}\text { Pcore } \\
\text { Post- } \\
\text { Test }\end{array}$ \\
\hline 1 & RAY & 50 & 75 \\
\hline
\end{tabular}

J-SHMIC, Vol 4, No 1, February 2017

\begin{tabular}{|c|c|c|c|}
\hline 2 & FR & 45 & 80 \\
\hline 3 & WR & 50 & 75 \\
\hline 4 & $\mathrm{RD}$ & 50 & 75 \\
\hline 5 & $\mathrm{NW}$ & 45 & 70 \\
\hline 6 & SP & 55 & 75 \\
\hline 7 & RSA & 60 & 80 \\
\hline 8 & $\mathrm{ZM}$ & 55 & 75 \\
\hline 9 & IPP & 55 & 75 \\
\hline 10 & MS & 45 & 75 \\
\hline 11 & $\mathrm{NL}$ & 60 & 80 \\
\hline 12 & ATK & 55 & 75 \\
\hline 13 & AR & 55 & 80 \\
\hline 14 & DSS & 60 & 70 \\
\hline 15 & NR & 55 & 80 \\
\hline 16 & $\mathrm{MF}$ & 50 & 75 \\
\hline 17 & RN & 60 & 80 \\
\hline 18 & SL & 45 & 70 \\
\hline 19 & SN & 60 & 85 \\
\hline 20 & $\mathrm{EF}$ & 55 & 75 \\
\hline 21 & SY & 50 & 75 \\
\hline 22 & RK & 45 & 75 \\
\hline 23 & APV & 60 & 80 \\
\hline 24 & LAR & 55 & 75 \\
\hline 25 & ASH & 45 & 70 \\
\hline 26 & DW & 60 & 80 \\
\hline 27 & $\mathrm{AH}$ & 55 & 75 \\
\hline 28 & $\mathrm{AG}$ & 55 & 75 \\
\hline 29 & DPE & 50 & 75 \\
\hline 30 & EHH & 55 & 75 \\
\hline 31 & EMS & 60 & 80 \\
\hline 32 & $\mathrm{FN}$ & 55 & 75 \\
\hline 33 & FM & 60 & 80 \\
\hline 34 & HD & 45 & 70 \\
\hline 35 & IS & 55 & 80 \\
\hline 36 & NS & 50 & 75 \\
\hline 37 & $\mathrm{RM}$ & 55 & 80 \\
\hline 38 & SHA & 55 & 80 \\
\hline \multicolumn{2}{|c|}{ Mean Score } & 57,5 & 80 \\
\hline
\end{tabular}

Table 3.3 shows the result of the formative test from the pre-test and post-test was an improved score pre-test, the mean score before 67,5 after post-test the mean score became 82,5 and improved score was 22,5 toward a formative test of cooperative learning based module. The students in pre-test who got score $<60$ were twenty-nine students, the other nine

Developing Cooperative Learning Based Module for Teaching Reading to the Second Semester Students at English Department of FKIP-UIR 
students got $>70$. After implementing cooperative learning based module at second semester students of FKIPUIR, there was a significant effect of improvement score. There were still twenty students who got score 70 until 75 and there are eighteen students got $>80$.

\section{CONCLUSIONS}

\section{a. The Validity and Practicality of Cooperative Learning based- Module}

\section{The Validity of Products}

Based on the advice of the five experts there were things that need to be repaired from the weaknesses of the module. The suggestions were very constructive so that module with cooperative learning was necessarily revised to be perfect. The suggestions were largely implemented in the module revision, but some were not.

\section{The Practicality of Products}

The results of the practicality cooperative learning based module were practical of implementing the use of cooperative learning in the learning process both in small groups and the trial limited field trials. During the limited field trials conducted practicality assessment cooperative learning based module by lecturers, practicality assessment by students, interviews with lecturers and students and the written test for students by the researcher.

\section{b. The Current Needs of Students}

Based on the findings and discussion of the cooperative learning based-module it can be concluded that Reading module can improve students' English reading comprehension of narrative texts, descriptive texts and hortatory exposition texts at the second semester of the English Department of FKIP-UIR. The findings show that the result of students' tests. It can be described that the students can improve their reading comprehension. They can answer the question based on indicators of reading comprehension of narrative texts, descriptive text, and hortatory exposition texts.

In addition, from the result of researcher after analyzing questionnaire, it was found that the student's needs were varied of all indicator of reading comprehension in narrative text, descriptive text, and hortatory exposition text. All of the text in the reading module were needed by the students to improve their reading comprehension.

\section{c. The design of cooperative learning Based Module}

Reading module for secondsemester students of FKIP-UIR with cooperative learning based-module has been designed. The products have been contributed in reading for second-semester students of FKIPUIR. The module is beneficial to enrich the teaching and learning in reading. The module has given a 
variety of text such as narrative text, descriptive text and hortatory exposition text for second-semester students of FKIP-UIR and showed the Validity and the practicality of the products which have been developed.

\section{d. Validity and Practicality of Cooperative Learning Based Module}

The effectivity of product in this research gave significant improvement towards the students' score result which was taken from the pre-test and post-test from secondsemester student of FKIP-UIR, and the products of this research are giving a very good result of achievement.

\section{REFERENCES}

Abbs, Peter and John Richardson. 1992. The Forms of Narrartive. Cambridge: Cambridge University Press.

Akker, Jan Van Den. 2006. Educational Design Research. New york: Rouledge.

Crandall, J. 1995. The Way and What, How, of ESL reading instructin: Some guidelines for writers of of ESL reading textbooks. In Byrd.

Coelho, E. 1992. Cooperative learning: Foundation for a communicative curriculum. In C. Kessler, cooperative language learning: A teacher's Resource Book. New York: Prentice Hall
Quible Zane K. Et al. 1996. Business Communication, Principles and Application, Singapore: Prentice Hall International, Inc.

Richards, J. C. 2001. Curriculum Development in Language Teaching. New york: Cambridge University Press.

Sullivan, Kathleen E. 1976. Paraghraph Practice (3rd edt). New York: Macmillan Publishing Co. Inc.

Swanson, K. R. Harris \& S. Graham (Eds.), Handbook of learning disabilities. New York: Guilford Press.

Tinker, M.A., \&McCullough, CM. 1975. Teaching elementary reading. Englewood Cliffs $\mathrm{NJ}$ : Prentice Hall.

Tomlinson, B. 1998. Materials Development in Langugae Teaching. New York: Cambridge University Press.

Vembriarto, St. 1985. Pengantar Pengajaran Modul. Yogyakarta: Yayasan Pendidikan Paramita.

Williams, J. P. 2003. Teaching Text Structure to Improve Reading Comprehension. In H. L.

Developing Cooperative Learning Based Module for Teaching Reading to the Second Semester Students at English Department of FKIP-UIR 